\title{
The Effect Of Roselle Extract (Hibiscus sabdariffa Linn.) On Blood Glucose Level And Total Antioxidant Level On Diabetic Rat Induced By Streptozotocin
}

\author{
Mardiah $^{1}$,Fransiska Rungkat Zakaria ${ }^{2}$, Endang Prangdimurti ${ }^{2}$, \\ Rizal Damanik ${ }^{3}$ \\ ${ }^{1}$ Department of Halal Food Science, Djuanda University, Bogor 16720 \\ ${ }^{2}$ Department of Food Science and Technology, Faculty of Agricultural Engineering, Bogor Agricultural \\ University, Kampus IPB Darmaga, Bogor-16680, Indonesia \\ ${ }^{3}$ Department of Community Nutrition, Faculty of Human Ecology, Bogor Agricultural University, Kampus IPB \\ Darmaga, Bogor-16680, Indonesia
}

\begin{abstract}
Roselle (Hibiscus sabdariffa Linn.) contains phenolic compounds, especially anthocyanins which act as antioxidants. The purposes of this study were to examine the antioxidant capacity and capability of purple roselle extract as an antidiabetics in diabetic rats induced by streptozotocin(STZ). A total of 24 male rats was used in this study. The rats were divided into six groups including group of normal rats as standard group $(S G)$, diabetic rats given distilled water $(\mathrm{DiW})$, diabetic rats given roselle extract $72 \mathrm{mg} /$ day/200 $\mathrm{g} \mathrm{bw}$ (DiR1), diabetic rats given roselle extract $288 \mathrm{mg} /$ day/200 $\mathrm{g} \mathrm{bw}($ DiR2), preventive rats (PR1) which were rats given roselle extract $72 \mathrm{mg} /$ day/200 $\mathrm{g}$ bw for 11 days then injected with STZ and continued with roselle extract $72 \mathrm{mg} /$ day/200 $\mathrm{g} \mathrm{bw}$ until the 21th day, and the last group was glibenclamide rats (DiG), were diabetic rats given glibenclamide $0.09 \mathrm{mg} /$ day/200g bw. Roselle extract was given orally administered $2 \mathrm{ml} /$ day/rat for 21 days. Results showed that blood sugar of DiR2, DiG and PR1 rat groups tended to decrease. Total antioxidant capacity ( TAC ) in DiRl (0.2655 $\pm 0.0016 \mathrm{mM})$ was same with others group (DiR2, PR1, DiG). Negative control rats $(\mathrm{DiW})$ had the lowest total antioxidant capacity $(0.0893 \pm 0.0134 \mathrm{mM})$. The content of malonaldehyde (MDA) of liver not significant $(P>0.05)$ but MDA of kidney was significant $(P<0.05)$, that DiR1, PR1, DiG, DiR2 was lower than in DiW. Insulin content analysis showed that DiR1 had the highest insulin levels $(0.4433 \pm 0.1802 \mathrm{ng} / \mathrm{ml})$ and differ significantly with DiW. Meanwhile groups of negative control rats (DiW) had the lowest insulin levels $(0.1286 \pm 0.0337 \mathrm{ng} / \mathrm{ml})$. It was concluded that roselle extract had the ability to lower blood sugar (both curative and preventive), increase of antioxidant capacity, and improve insulin production.
\end{abstract}

KEYWORDS - blood glucose, roselle, streptozotocin, total antioxidant capacity

\section{INTRODUCTION}

Diabetes Melitus (DM) is a metabolic disorder characterized by hyperglycemia associated with abnormalities in the metabolism of carbohydrates, fats and proteins and caused by a decrease in insulin secretion or insulin sensitivity, or both. The diseases may cause microvascular and macrovascular complications ([1]; [2]). Diabetes melitus is classified into two types, insulin dependent diabetes melitus (IDDM, Type 1) and noninsulin-dependent diabetes melitus (NIDDM, Type 2). Type I diabetes is an autoimmune disease characterized by a local inflammatory reaction in and around islets that is followed by selective destruction of insulinsecreting $\beta$ cells. Type II diabetes is characterized by peripheral insulin resistance and impaired insulin secretion [3].

Hyperglycemic conditions can result inthe formation of reactive oxygen species (ROS). Excessive ROS can cause oxidative stres and exacerbate damage to the $\beta$ cells ([4];[5]). ROS can also decrease the intracellular antioxidant [6]. Hyperglycemia can lead to increased lipid peroxidation, superoxide production, lipoprotein glycation, oxidative DNA damage, platelet aggregation and activation, and a decreased production of prostacyclin [7]. Lipid peroxidation results in malonaldehyde (MDA), acrolein, and 4hydroxynonenal (4 HNE) commonly used as biomarkers to assess lipid peroxidation of biological oxidative stres. MDA is formed after radical compounds attack membrane lipids containing polyunsaturated fatty acids (PUFAs) ([8];[9];[10]). 
Roselle (Hibiscus sabdariffa Linn.) has been believed for many years to be able to reduce the risk of degenerative diseases. Several studies have shown that roselle was effective in lowering blood pressure ([11];[12];[13];[14];[15]), had an antioxidant function protecting the liver from a damage ([16];[17];[18];[19]), increased the antioxidant enzymes in the liver [20], was anti-inflammatory and analgesic [21], and was found to lower uric acid ([22];[23]). Roselle has high antioxidant content. The highest components in roselle are anthocyanins, a flavonoid group. Anthocyaninsfound in roselle are delphinidin-3-sambubioside, cyanidin-3 sambubioside, and delphinidin-3- glucose [24]. Beside anthocyanins, it also contains alkaloids, L- ascorbic acid , anisaldehid, $\beta$-carotene, $\beta$-sitosterol, citric acid, galactose, gossypetin, hibiscetin, and mucopolysaccharides [25].

ROS or free radicals can be neutralized and destroyed by antioxidants present in the body so that the biological damage by these compounds can be avoided [6]. The purpose of the research was to evaluate whether roselle would increase the antioxidants in the body, reduce oxidative stresand improve insulin production in diabetic rats induced by streptozotosin.

\subsection{Roselle Extraction}

\section{MATERIALS AND METHODS}

Petals of purple roselle (Hibiscus sabdariffa Linn.) were obtained from Leuwiliang plantation, Bogor, West Java. Fresh roselle was dried using oven with a temperature of $60^{\circ} \mathrm{C}$ for 6 hours. Dried roselle were then boiled with water for 10 minutes at a concentration of $2 \mathrm{~g} / 200 \mathrm{ml}$. Roselle extract was concentrated $10 \mathrm{ml}$ by vacuum evaporator and stored at $4{ }^{\circ} \mathrm{C}$.

\subsection{Experimental Animals}

All animal experimental protocol used in this study was approved by Health Development and Research Committee, Health Ministry, Republic of Indonesia with ethical clearance No.LB.02.01/5.2/KE.446/2013. Male Sprague Dawley (SD) rats $(200 \pm 30 \mathrm{~g}), 8$ weeks old, used in the studies were purchased from BPPOM (National agency for drug and food control), Jakarta. All animals were housed in laboratory conditions for one week before experiments began. Rats were allowed free access to drinking water (ad libitum) and were maintained at a constant temperature of $24-26^{\circ} \mathrm{C}$ and $50-60 \%$ relative humidity conditions. Before the experiment, rats were adapted to the laboratory diet [26] for 7 days.

\subsection{Diabetes Induction}

Diabetic condition of rats was induced experimentally by intraperitoneal injection of freshly prepared streptozotocin (STZ)(Sigma,USA) solution at a dose of $30-35 \mathrm{mg} / \mathrm{kg}$ body weight in $0.1 \mathrm{M}$ cold citrate buffer, $\mathrm{pH} 4.5$ [27]. Blood was collected from the tail vein after $72 \mathrm{~h}$ and glucose levels were determined using glucometer test kit. Animals were considered diabetic if the testing blood glucose values were always above $200 \mathrm{mg} / \mathrm{dl}$. If blood glucose levels did not reach>200mg/dl, then rats were re-injected with the same dose of streptozotosin. Control rats received citrate buffer $(\mathrm{pH} 4.5)$ alone.

\subsection{Experimental Design}

Rats were randomly divided into six groups, (four rats per group). In group one (SG): the rats were not induced by STZ, and were given drinking water only. In group two (DiG) diabetic rats were given glibenklamide $0.09 \mathrm{mg} /$ day/200 $\mathrm{g}$ bw; In group three (DiW) diabetic rats were given drink water only. In group four (PR1) rats were treated with roselle extract $2 \mathrm{ml} /$ day (for $2 \mathrm{ml}$ contains $72 \mathrm{mg} / \mathrm{day} / 200 \mathrm{~g} \mathrm{bw}$ ) for 10 days prior to injectioned with STZ, and then treated with roselle extract until 21th day. In group five (DiR1), diabetic rats were treated with roselle extract $(72 \mathrm{mg} / \mathrm{day} / 200 \mathrm{~g} \mathrm{bw})$. In group six (DiR2) diabetic rats were treated with roselle extract $2 \mathrm{ml} / \mathrm{day}$ (for $2 \mathrm{ml}$ contains $288 \mathrm{mg} / \mathrm{day} / 200 \mathrm{~g} \mathrm{bw}$ ). The roselle extract was administered 2 $\mathrm{ml} /$ day by orally. Feed was given approximately $25 \mathrm{~g} / \mathrm{rat} /$ day. During treatment period glucose levels were measured 2 to 3 times in all groups of treated rats.

At the end of the treatment period, all rats were anaesthetized with ether and the body was cleaned by alcohol. Further, the peritoneal was opened, and blood sampling by using the syrinx. Blood of rats from each group was collected and centrifuged at $1870 \mathrm{~g}$ for $15 \mathrm{~min}$ at $4^{\circ} \mathrm{C}$. Rat body organs were washed in a PBS (phosphate buffered saline) solution, drained, and weighed. The organs were then wrapped in aluminum foil and stored in a freezer at $-20^{\circ} \mathrm{C}[28]$. 


\subsection{Analysis of Samples}

Analysis of blood glucose was done by using an Accucheck glucometer (Roche,Germany). Troloxequivalent antioxidant capacity (TEAC) method (Antioxidant assay kit CSO790, Sigma Aldrich, USA) was applied. The method is based on the formation of the ABTS•+ cation [2,2'- azinobis (3ethylbenzothiazoline-6-sulfonic acid)] and its scavenging by antioxidant sample constituents (plasma) measured by spectrophotometry. Decay of green/blue chromophore absorbance is inversely associated with antioxidant content and the control antioxidant is Trolox, a hydrophilic vitamin $\mathrm{E}$ analog.

Insulin assay was transformed in a commercial kit (Biorbyt ORB54820, USA) using sample of rat blood plasma. This assay is a two site ELISA. The microplate is precoated with a monoclonal antibody against insulin. Standard and samples are added into the wells and co-incubated with a monoclonal antibody conjugated to horseradish peroxidase (HRP) enzyme. After washing step to remove any unbound substances, TMB substrate is added and colour develops in proportion to the amount of insulin bound initially.

Analysis of malonaldehyde (MDA) was done on rat liver and rat kidney. MDA measurements was carried out following the procedures [29]. A total of $0.5 \mathrm{ml}$ of liver supernatant plus $2.0 \mathrm{ml}$ of cold $\mathrm{HCl}(0.25 \mathrm{~N})$ containing $15 \%$ TCA, TBA $0: 38 \%$ and $0.5 \%$ BHT. The mixture was heated at $80^{\circ} \mathrm{C}$ for 1 hour. Once cool, the mixture was centrifuged at $822 \mathrm{~g}(3500 \mathrm{rpm})$ for 10 minutes. The absorbance of the supernatant was measured at $532 \mathrm{~nm}$. As the standard solution, a TEP (tetraetoksipropana) was used.

\subsection{Statistical Analysis}

Statistical analysis was performed in Mean \pm STD. Analyses of data using ANOVA.

\section{RESULTS}

Diabetes was characterized by increased levels of blood glucose. The blood glucose data derived from the calculation of average blood sugar level on 4 rats during the treatment period were shown in Fig. 1. In Fig. 1, day 7th was the induction day with STZ and after 2-3 days rats were hyperglycemic indicated by an increase of blood glucose $>200 \mathrm{mg} / \mathrm{dl}$. Treatments with roselle were given after the rats showed some hyperglycemia symptoms including high diuretic, skin turgor, high feed intake, lost body weight. Fig. 1 also showed that rats given roselle extract $72 \mathrm{mg} / \mathrm{day} / 200 \mathrm{~g}$ bw (DiR1) had a decrease of blood glucose level on day $14^{\text {th }}$, but increased again until the end of the treatment period. Meanwhile rats given roselle extract $288 \mathrm{mg} / \mathrm{day} / 200 \mathrm{~g} \mathrm{bw}$ (DiR2) had a decrease of blood glucose level from day $14^{\text {th }}$ until the end of the treatment period. Negative control rats (DiW) had decreased of blood glucose level on days 7th and 14th, but the blood glucose level increased again until the end of the treatment period. Rats fed glibenclamide drug $(\mathrm{DiG})$ had a decreased of blood glucose level on days 14th. However this blood glucose level was found to increase on day 21th and decrease again in the end of the treatment period.

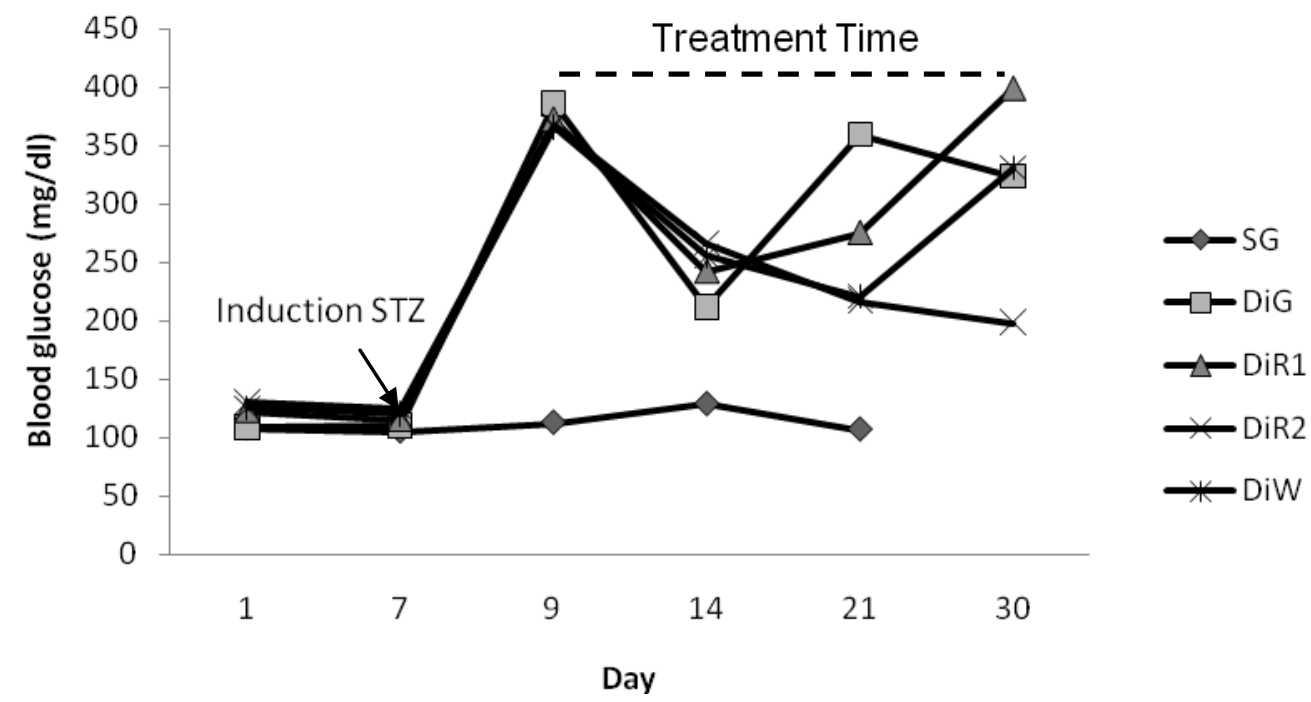

Fig. 1. Average of blood glucose of treated rats (day 1 first level of blood glucose ; day 7, STZ induction, the 9th21 th day treatment time with roselle (DiR1,DiR2); with glibenclamide (DiG); control (SG) and negative (DiW). 
Fig. 2 showed blood glucose of PR1 rats that were induced with STZ after the rats were given roselle extract $72 \mathrm{mg} / \mathrm{day} / 200 \mathrm{~g}$ bw for 10 days. The rats had hyperglycemia 2 to 3 days after. Once the conditions of hyperglycemia (blood glucose $>200 \mathrm{mg} / \mathrm{dl}$ ) were obtained, the rats were given roselle again until days $21 \mathrm{st}$. These rats were found to suffer from hyperglycemia from day 13th until day 18th and after that blood glucose decrease until the end of the experiment.

Symptoms of diabetes among other things are a lot of eating, lots of drinking accompanied by loss of weight. These symptoms are seen in Fig. 3 and Fig. 4. It was shown in Fig. 3 that the average feed comsumption of diabetic-induced rats in DiW, DiG, DiR1, DiR2 were higher than that of normal rats (SG). In preventive rats (PR1), the average feed consumption before the rats became diabetic was lower than that of normal rats $(\mathrm{SG})$. However after having diabetes their average feed consumption increased to a level above that of normal rats $(\mathrm{SG})$.

Fig. 4 describes the changes in body weight, where the negative control rats (DiW) lost weight during the treatment period. Rats in normal group (SG) tended to gain weight. Preventive rats (PR1) initially gained weight, but after being induced with STZ they lost weight showing a diabetes condition. Meanwhile body weight of rats in the other groups (DiR1, DiR2, DiG) was relatively constant.

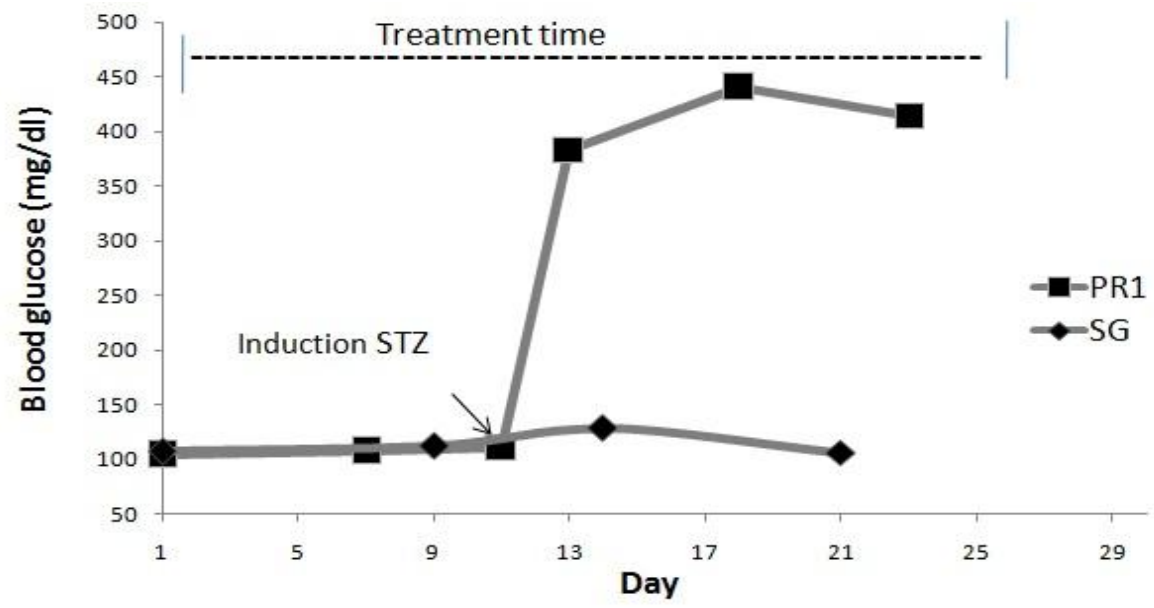

Fig. 2. Average blood glucose of rats (PR1), given roselle extract $72 \mathrm{mg} /$ day/200g bw for 10 days, . Day 11 th was the induction time with STZ. After 3 days rats had hyperglycemia and were continued to receive roselle until day 21.

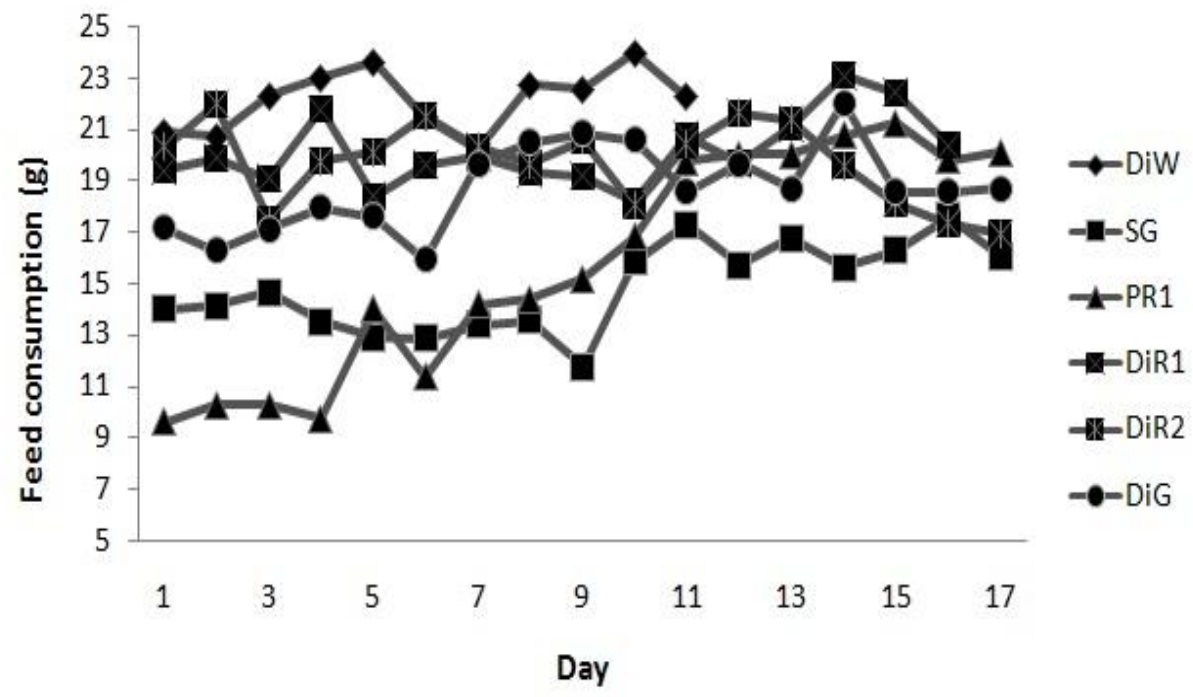

Fig. 3. Feed consumption of treatment rats (control (SG); glibenclamide (DiG) roselle extract $72 \mathrm{mg} / \mathrm{day} / 200 \mathrm{~g}$ bw (DiR1); roselle extract $288 \mathrm{mg} /$ day/200g bw (DiR2); preventive (PR1); negative (DiW) 
The effect roselle extract on total antioxidant capacity (TAC), insulin and malonaldehyde (kidney) had expressed on Table 1 significant difference $(\mathrm{p}<0.05)$ was found in different groups, except malonaldehyde in liver. Table 1 showed that rats treated roselle extract $72 \mathrm{mg} / \mathrm{day} / 200 \mathrm{~g}$ bw (DiR1), DiR2, PR1 and DiG were not differ significantly but differ significantly with DiW. Rats in the negative group (DiW) had the lowest total antioxidant capacity.

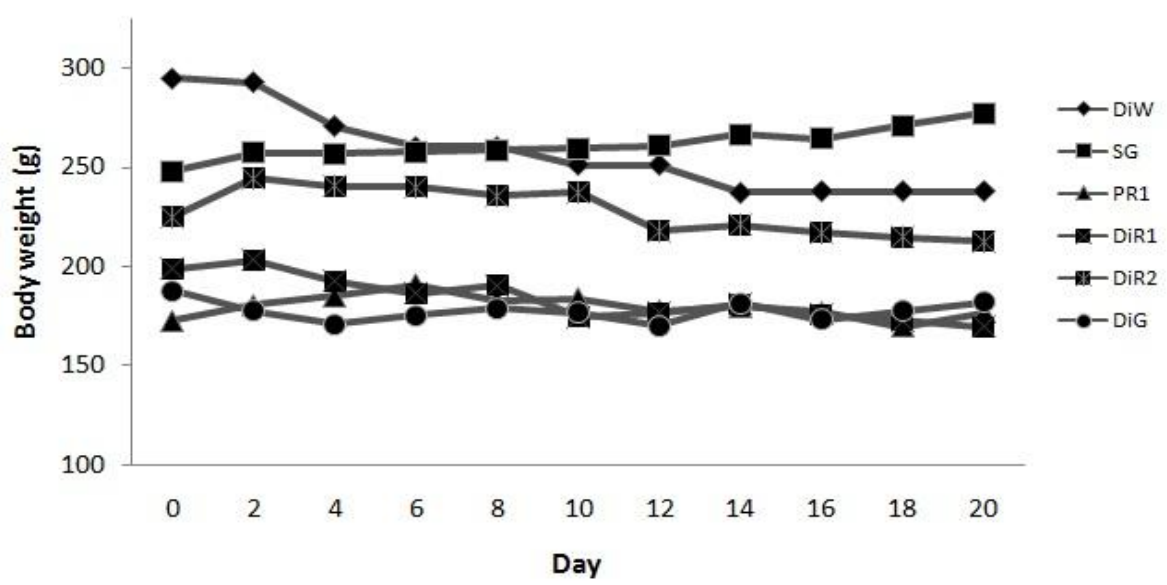

Fig. 4. Changes of rat body weight (control (SG); glibenclamide (DiG); roselle extract $72 \mathrm{mg} /$ day/200g bw (DiR1); roselle extract 288mg/day/200g bw (DiR2); preventive (PR1); negative (DiW).

MDA which is a marker of oxidative stres was found to be markedly different (Table 1). Data showed that rats in the negative control (DiW) had MDA levels (kidney) higher than those others group (PR1, DiG, DiR1, DiR2). Meanwhile in MDA of liver showed data were not differ significantly (P>0.05). Results of insulin analysis showed that the group of rats treated with roselle extract $72 \mathrm{mg} / \mathrm{day} / 200 \mathrm{~g}$ bw (DiR1) had the highest blood insulin content. Rats in DiR2, PR1 and DiG groups were found to have relatively similar insulin content. Meanwhile rats in negative (DiW) group had the lowest insulin levels.

Table 1. Average content of insulin and total antioxidant capacity in blood plasma and malonaldehyde in rat liver and rat kidney

\begin{tabular}{|c|c|c|c|c|}
\hline \multirow[t]{2}{*}{ Treatment $* * *$} & \multirow[t]{2}{*}{ Insulin (ng/ml) } & \multicolumn{2}{|c|}{ MDA $(\mathrm{nmol} / \mathrm{g}) *$} & \multirow[t]{2}{*}{$\mathrm{TAC}(\mathrm{mM})^{* *}$} \\
\hline & & Liver & Kidney & \\
\hline SG & $0.1968 \pm 0.0486^{\mathrm{ab}}$ & $1.0966 \pm 0.2351^{\mathrm{a}}$ & $4.6611 \pm 0.4151^{b}$ & $0.1659 \pm 0.0192^{\mathrm{ab}}$ \\
\hline DiW & $0.1286 \pm 0.0337^{\mathrm{a}}$ & $1.3666 \pm 0.1978^{a}$ & $5.1952 \pm 0.3789^{b}$ & $0.0893 \pm 0.0134^{\mathrm{a}}$ \\
\hline PR1 & $0.3516 \pm 0.1528^{a b}$ & $1.2907 \pm 0.1698^{\mathrm{a}}$ & $3.8166 \pm 0.5866^{\mathrm{a}}$ & $0.2318 \pm 0.0038^{b c}$ \\
\hline DiR1 & $0.4433 \pm 0.1802^{\mathrm{b}}$ & $1.0954 \pm 0.4282^{\mathrm{a}}$ & $3.5558 \pm 0.1190^{\mathrm{a}}$ & $0.2655 \pm 0.0016^{\mathrm{c}}$ \\
\hline DiR2 & $0.2918 \pm 0.1083^{a b}$ & $1.1865 \pm 0.4728^{\mathrm{a}}$ & $3.6188 \pm 0.1936^{\mathrm{a}}$ & $0.1868 \pm 0.0962^{\mathrm{bc}}$ \\
\hline $\mathrm{DiG}$ & $0.3504 \pm 0.1853^{\mathrm{ab}}$ & $1.1444 \pm 0.3718^{\mathrm{a}}$ & $3.8348 \pm 0.1146^{\mathrm{a}}$ & $0.2109 \pm 0.0055^{b c}$ \\
\hline
\end{tabular}

Values (Mean \pm SE) with different superscripts in a row differ significantly $(\mathrm{P}<0.05)$

*MDA (malonaldehyde)

**TAC (Total Antioxidant Capacity)

***control normal (SG); negative (DiW);rroselle $72 \mathrm{mg} /$ day/200g bw (DiR1); roselle $288 \mathrm{mg} /$ day/200g bw (DiR2); preventive rats (PR1);glibenclamide (DiG). 


\section{DISCUSSION}

Streptozotocin (STZ) is a chemical used to induce diabetes in experimental animals. This compound provides acute cytotoxic effects on cells and molecules, especially against pancreatic $\beta$ cell. Damaged pancreatic $\beta$ cells lead to reduced insulin and causes hyperglycemia ([29];[30];[31]). STZ generates free radicals such as superoxide radical $\mathrm{O}_{2}^{-}, \mathrm{H}_{2} \mathrm{O}_{2}$ and $\mathrm{OH}^{-}$including nitric oxide which causes DNA damage [31]. Hydroxyl group $\left(\mathrm{OH}^{-}\right)$is a very strong oxidizing compounds that can react with DNA, proteins, lipids, amino acidsand glucose [8]. DNA damage causes the $\beta$ cells of the pancreas unable to produce insulin so that blood glucose increases (hyperglycemia). According to [4] hyperglycemic conditions may result in the formation of ROS (reactive oxygen species ) such as $\mathrm{O}_{2}^{-}$and peroxide [6]. The formation of free radicals is stimulated by $\mathrm{H}_{2} \mathrm{O}_{2}$ in pancreatic $\beta$ cells [27]. Excessive ROS can cause oxidative stres and can exacerbate damage to pancreatic $\beta$ cells. Oxidative stres can decrease the number of insulin-producing $\beta$ cells in the pancreas [31]. In STZ-induced diabetic rats, diabetes develops as a result of irreversible pancreatic $\beta$-cell destruction leading to degranulation and reduced insulin secretion. In Figure 1 and Figure 2 all rats injected with streptozotocin (PR1, DiG, DiW, DiR1, DiR2) experienced hyperglycemia characterized by increased levels of blood sugar (> 200 $\mathrm{mg} / \mathrm{dl})$.

Fig.1 showed that negative control rats (DiW) had a lost body weight and a decrease blood glucose level after being induced with streptozotocin $30-35 \mathrm{mg} / \mathrm{kg}$ body weight. This might due to the notion that pancreas cells could still produce insulin before they were damaged. According to [32] admininistration of STZ in low concentration had the tendency to make insulin secreted fom pancreas cells and the remaining cells escaping from the attack of STZ might cause an over secretion of insulin to maintain normoglycemia. Similar notion was expressed by [33] stating that administration of low doses of STZ would still allow pancreatic cells to produce insulin.

Fig. 1 showed that the levels of blood glucose in rats of DiR2 group decreased indicating that roselle was capable of lowering blood glucose level in diabetic rats induced by STZ. Decreased levels of glucose showed an improvement in the number of $\beta$ cells producing insulin in pancreatic cells. Rats treated with glibenclamide drug as a positive control in this study also showed a decrease in blood sugar levels. According to [34] glibenclamide has the same mechanism in lowering blood sugar through the mechanism of stimulation of insulin secretion. In addition, glibenclamide prevents glucagon secretion. It was shown in Fig. 2, that in preventive (PR1) group had high blood glucose levels after being induced with streptozotocin. However, the pancreatic $\beta$ cells of these rats seemed to get repaired so that they were capable of producing insulin, as indicated by decreased blood glucose levels at the end of the treatment period. The presence of insulin (Table 1) showed the restoration of pancreatic cells after being damaged by streptozotocin. In rats with restored cell function, the proportion of insulin-positive cells in the islets was increased [35]. Rats given roselle extract 72 $\mathrm{mg} / \mathrm{day} / 200 \mathrm{~g}$ bw (DiR1) had the highest insulin levels among rats of the other groups. However, as can be seen in Fig.1, there was no correlation between the amount of serum insulin and the lowering blood glucose levels. This indicates that there is a occurrence of a symptom of insulin resistance in type 2 diabetes mellitus in rats of that group. According to [32], in rats administered with STZ, non-fasting serum glucose level continued to increase gradually after STZ administration without affecting the non-fasting serum insulin levels. In addition, they were shown to produce type 2 or non-diabetes insulin dependent diabetes mellitus. It was stated further that ([36];[37]) insulin resistance occurred as a result of damages in insulin receptors which was related to the existence of free radicals.

The hallmark of diabetes mellitus is polyuria-excessive urine production, polydipsia-excessive thirst and polyphagia-excessive eating, dehydration, lost of weight, no balancing of electrolyte, and ketoacidosis ([6]; [38]; [33]). The measurement of skin turgor and observation of cage bedding for urine output acted as a surrogate marker of thirst [33]. In Fig. 4 body weight of rats in negative control groups (DiW) decreased quite a lot while that body weight of the rats in the normal group (SG) tended to increased. In their studies [39] and [40] obtained similar results in that STZ induced rats had body weight loss while normal rats had increased body weight during the treatment period. In diabetic condition, the body will take energy from the adipose cells because body cells have trouble getting energy from sugar due to insulin resistance [41]. This leads to decreased body weight due to the degradation of fat cells (lipolysis). The decrease in body weight in diabetic rats may indicate loss or degradation of structural proteins, which have been reported to contribute to body weight [42]. Results of a study by Yin et al. (2006) indicated that compared to those in normal control, rats administered with streptozotocin experienced a reduction in the proportion of insulin positive cells and an increase in glucagon positive cells. Glucagon induce lipolysis and glukoneogenesis.

The average body weight of rats in DiG group was relatively constant. Similar results in rats treated with glibenclamide group were also expressed by [42] who found that glibenclamide did not give any change in body weight of STZ diabetic induced rats. Polyphagia conditions can be seen in Fig. 3 where rats in the negative control group (DiW) consumed feed most but had decreased body weights (Fig. 4). 
In diabetic condition oxidative stres may occur as indicated by higher amount of prooxidants than antioxidants. MDA is a highly reactive compound that is the end product of lipid peroxidation, and is usually used as a biomarker to assess lipid peroxidation of biological oxidative stres. The level of lipid peroxidation can be suppressed by the presence of antioxidants. In diabetes, protein oxidation (protein carbonylation) and lipid peroxidation (MDA) also increase ([5]; [7]; [27]; [40]). In this study,malonaldehyde of negative control (DiW) rats had higher MDA kidney than did rats of the other groups. Malonaldehyde kidney from DiR1, DiR2, PR1 and $\mathrm{DiG}$ was lower than that from DiW. It was indicated that roselle was able to reduce the amount of lipid peroxidation by free radicals in asshown by the the results which were almost the same as the one ofthe positive control group (SG). Tseng et al. [16] found that roselle contained hibiscus protocatechuic acid (PCA),a simple phenolic compound capable of functioning as an antioxidant at a concentration of $0.05 \mathrm{mg} / \mathrm{ml}$ and $0.10 \mathrm{mg} / \mathrm{ml}$. PCA is able to decrease lactate dehydrogenase and alanine transaminase and decrease the formation of malonaldehyde. Reducing lipid peroxidation is particularly important to indicates lower levels of oxidative stres [5].

Total antioxidant capacity shows overall amount of antioxidants in the body. The advantage of this test is that it measures all antioxidant, not just in a bioactive component [43]. In this study, it was shown that total antioxidant capacity (TAC) in DiR1, DiR2, DiG, PR1 was higher than that in DiW group. This showed that rats fed roselle could increase total antioxidant capacity. According to [6] hyperglycemic conditions can lower total plasma antioxidant capacity in patients with and without diabetes. STZ induced diabetic rats have decreased antioxidant enzymes such as superoxide dismustase, catalase and glutathione peroxidase which would lower the total antioxidant in the body ([44];[40]). Anthocyanin pigments contained in the roselle drink can reduce oxidative stres due to an increased number of free radicals in the body of diabetic rats. Anthocyanins can provide electrons or $\mathrm{H}$ atoms to free radicals so that these compounds can be stable and free-radical chain reactions can be stopped [45]. In addition, roselle has other compounds such as quercetin, ascorbic acid, and protocatheuic acid (PCA) that function as antioxidants [25]. Vitamin C plays a role as scavenger, and has an ability to donate electrons to ROS to make it stable [8]. According [46] states that phytochemical contents in roselle extract in water are flavonoids $(1.08 \%)$, saponins $(1.13 \%)$, alkaloids $(12.09 \%)$, tannins $(12.07 \%)$, total phenols $(0.05 \%)$, and glycosides $(0.05 \%)$. Roselle is able to increase glutathione peroxidase and catalase in liver of treated rats compared with that in control mice [20]. These enzymes are able to play a role in improving pancreas cells in diabetic rats ([42]; [47]) as well as in rats suffering from complications such as neuropathy due to diabetes [6]. According [5] found that in diabetic rats, treatment with antioxidants reduces signs of oxidative damage in the pancreas. Mechanisms which can be described in this study is that roselle has some amount of antioxidant that can donate $\mathrm{H}^{+}$ions and function as a metal chelator (containing polyphenols) that can bind $\mathrm{Fe}^{2+}$. Through these functions, antioxidant can indirectly lower the Fenton reaction and prevents oxidation caused by increased hydroxyl radicals. Polyphenols can also induce the body's antioxidant enzymes (SOD,catalase) which is able to decompose hydroperoxide, $\mathrm{H}_{2} \mathrm{O}_{2}$ and superoxide anion and inhibits the expression of the enzyme xanthinoxidase [45]. In this study treatment with roselle extract increased total antioxidant capacity, reduced MDA as a marker of oxidative stres and increased insulin as an evident of damage repair in pancreas.

\section{CONCLUSION}

Hyperglycemia causes a condition in which the body produces free radicals that can damage cells and cause a reduction in pancreatic insulin. The role of antioxidants in roselle could reduce the amount of free radicals formed. This was indicated by the finding that pancreatic $\beta$ cells were able to repair and produce insulin in amount which was higher than in negative control rats. Roselle extract could increase the antioxidant capacity of the body to protect the body from damages caused by hyperglycemia. Roselle extract could decrease malonaldehyde in kidney as marker oxidative stres. The results of this study showed that rats induced with STZ of 30-35 mg / kg had damaged pancreatic cells, but these cells could still be repaired as indicated by the ability of the cells to produce insulin.

\section{VI.ACKNOWLEDGEMENT}

The authors are thankful to Ministry of Education and Culture for the financial support of this project (BPPS) and to PT. Garuda Food for providing TAC kits.

\section{REFERENCES}

[1] Sukandar, Yulinah, Elin, Andrajati, Retnosari, I.Sigit, Joseph,Adyana, K.I.Setiadi, A.Prayitno, and A.Kusnandar, ISO farmakoterapi (Jakarta :PT ISFI,2008).

[2] F.Giacco, and M.Brownlee, Pathogenesis of microvascular complication, in R.I.G. Holt, C. Cokram,A.Flyvbjerg,B.J.Goldstein, (eds), Textbook of diabetes, 4 (UK: A John Wiley \&Sons Ltd Publ., 2010)

[3] A.J.Delli, H.E. Larsson, S.A.Ivarsson, and A.Lernmark, Type I diabetes, in R.I.G. Holt, C. Cokram,A.Flyvbjerg,B.J.Goldstein, (eds), Textbook of diabetes, 4 (UK: A John Wiley \&Sons Ltd Publ., 2010)

[4] R.P.Robertson, J.Harmon, P.O.Tran, Y.Tanaka, and H.Takahashi, Glucose toxicity in $\beta$ cell type 2 diabetes, good radical gone bad and the gluthatione connection, Diabetes, 52, 2003, 581-587. 
[5] Pazdro and J.R.Burgess, The role of vitamin E and oxidative stres in diabetes complications, Mechanism of Ageing and Development, $131,2010,276-286$.

[6] A.M.Vincent, J.W. Russell, P. Low, and E.L.Feldman, Oxidative stres in the pathogenesis of diabetic neuropathy , Endocrine Reviews, 25(4), 2004, 612-628.

[7] M.A.Cser, L. Sziklai, F.L.Mauriceand, and L.Ingrid, Antioxidant status of insulin dependent diabetics, in J.T.Kumpulainen, and J.T. Salonen, (eds), Natural antioxidants and anticarcinogens in nutrition, (Finland:The Royal Society of Chemistry, 1999).

[8] Kohen and Nysta, Invited review : oxidation of biological system :oxidative stres phenomena, antioxidant, redox reaction and methods for their quantification, Toxicolpathol, 30(6), 2002, 620-650.

[9] E. Skrzydlewska, S.Sulkowski, S.M.Koda, B.Zalewski, L.K.Koda, and M.Sulkowska, Lipid peroxidation and antioxidant status in colorectal cancer, World Journal of Gastroenterology, 11(3), 2005, 403-406.

[10] T.P.A.Devasagayam, K.K. Boloor, and T.Ramasarma, Methods for estimating lipid peroxidation:An analysis of merits and demerits, Indian Journal of Biochemistry and Biophysics, 40, 2003. 300-308.

[11] P.C.Onyenekwe, E.O.Anjani, D.A.Ameh, and K.S.Gamaniel, Antihypertensive effect of roselle (Hibiscus sabdariffa) calyx infusion in spontaneously hypertensive rats and a comparison of its toxicity with that in wistar rats cell, Biochechemistry Functional, 17(3), 1999, 199-206.

[12] A.Herrera, S.F.Romero, M.A.Chavez-Soto, and J.Tortoriello, Effectiveness and tolerability of a standardized extract from Hibiscus sabdariffa in patientswith mild to moderate hypertension: a controlled and randomized clinical trial, Phytomedicine, 11, 2004,375382.

[13] M.Faraji, and A.Tarkhari,. The effect of sour tea (Hibiscus sabdariffa) on essential hypertension, J. Ethnopharmacol, 65(3), 1999, 231-236.

[14] B.J.Adegunloye, J.O.Omoniyi, O.A. Owolabi, O.P.Ajagbonna, O.A.Sofola, and H.A.Coker, Mechanisms of the blood pressure lowering effect of the calyx extract of Hibiscus sabdariffa in rats, Afr. J. Med. Sci., 25(3), 1996. 235-238.

[15] D.L.McKay, C.Oliver, S.Edward, and B.B.Jeffrey, Hibiscus sabdariffa Linn. Tea (Tisane) lowers blood pressure in prehypertensive and mildly hypertensive adults, TheJournal of nutrition, 140(2), 2010.298-303.

[16] T.H.Tseng, E.S. Kao, C.Y.Chu, F.P. Chou,H.W.Lin Wu, and C.J.Wang, Protective effects of dried flower extracts of Hibiscus sabdariffa Linn. against oxidative stres in rat primary hepatocytes, J.of Food Chem. Toxicol., 35(12), 1997, 1159-1164.

[17] T.H,Tseng, C.J.Wang, E.S.Kao, and H.Y.Chu, Hibiscus protocatechuic acid protects against oxidative damage induced by tertbutylhydroperoxide in rat primary hepatocytes, Chem. Biol. Interact., 101(2), 1996. 137-148.

[18] S.S. El-Saadany, M.Z.Sitohy, S.M.Labib, and R.A.El-Massry, Biochemical dynamics and hypocholesterolemic action of Hibiscus sabdariffa (Karkade), Entrez Pub. Med. Nahrung, 35(6), 1991, 567-576.

[19] D. Dahiru, O.J.Obiand, and H.Umaru, Effect of Hibiscus sabdariffa calyx extract on carbon tetrachloride induced liver damage, Biokemistri, 15(1), 2003, 27-33.

[20] T.Okoko, and F.O.Ibiba, The effect of Hibiscus sabdariffa calyx extract on cisplatin-induced tissue damage in rats, Biokemistri, 20(2), 2008, 47-52.

[21] W.Reanmongkol, and A. Itharat, Antipyretic activity of the extracts of Hibiscus sabdariffa Linn. calyces in experimental animals, Songklanakarin Journal ScienceTechnology, 29(1), 2007, 29-38.

[22] S.Kirdpon, S.N.Nakorn, and W.Kirdpon, Changes in urinary chemical composition in healthy volunteers after consuming roselle (Hibiscus sabdariffa Linn.) juice, J. Med. Assoc. Thailand,77(6), 1994, 314-321.

[23] C.Y.Kuo, E.S.Kao, K.C.Chan, H.J.Leeb, T.F.Huang, and C.J.Wang, Hibiscus sabdariffa Linn. extracts reduce serum uric acid levels in oxonate-induced rats, Journal of Functional Foods,4, 2012, 375-381.

[24] K.R.Christian, M.G.Nair, and J.C.Jackson, Antioxidant and cyclooxygenase inhibitory activity of sorrel (Hibiscus sabdariffa). J Food Compos Anal.,19, 2006, 778-783.

[25] V. Hirunpanich, A. Utaipat, N.P. Morales, Bunyapraphatasaran, H.Sato, A. Herunsale and C. Suthisiang, Antioxidant effects of aqueous extracts from dried calyx of Hibiscus sabdariffa Linn. (Roselle) in vitro using rat low-density lipoprotein (LDL), Biol. Pharm. Bull, 28(3), 2005, 481-484.

[26] P.G.Reeves, Components of the AIN-93 diets as improvements in the AIN-76A Diet, The Journal of Nutrition, (127):5, 1997.

[27] M.Gayathri, and K.Kannabiran, The Effects of oral administration of an aqueous extract of Ficusbengalensis stem bark on some hematological and biochemical parameters in rats with streptozotocin-induced diabetes, Turk J Biol., 33, 2009.9-13.

[28] N.F.Girgis, S.Kamel, B.Labib, S.E.H.Naby, and S.Samy, Cellular and DNA changes due to clonazepam abuse in brains of albino rats and role of clonidine during withdrawal period, ,J.ForensicMed.Clin.Toxicol,18(1), 2010, 25.

[29] R.P.Singh, K.N.C.Murthy, and G.K.Jayaprakasha, Studies on the antioxidant activity of pomegranate (Punicagranatum) peel and seed extracts using in vitro models, J. Agric. Food Chem., 50, 2002 81-86.

[30] J.S.Kim, J.B.Ju, C.W.Choi, and S.C.Kim, Hypoglycemic and antihyperlidemic effect of four Korean medicinal plants in alloxan induced diabetic rats, Am.J.Boichem.Biotech, 2, 2006,154-160.

[31] T.Szkudelski, The mechanism of alloxan and streptozotocin action in $\beta$ cells of the rat pancreas, Physiol.Res., 50(6), 2001, 537-546.

[32] S.Arora, S.K.Ojha, and D.Vohora, Characterisation of streptozotocin induced diabetes mellitus in Swiss albino mice, Global Journal of Pharmacology, 3 (2), 2009, 81-84.

[33] M.L.Graham, J.L.Janecek, J.A.Kittredge, B.J.Hering, and H.J.Schuurman, The Streptozotocin-induced diabetic nude mouse model: differences between animals from different sources, Comparative Medicine, 61(4), 2011,356-360

[34] L.F. Valverde, F.D.Cedillo, M.L.Ramoz, E.G.Cervera, E.P.Gomez, C.C.Arredondo, and G.A.Leon, Glibenclamide-pregnenolone derivative has greater hypoglycaemic effects and biodistribution than glibenclamide-OH in alloxan rats, Biomed Pap Med Fac.Univpalacky Olomouc Czech Repub., 156(2), 2012, 122-127.

[35] D.Yin, J.Tao, D.D.Lee, J.Shen, M.Hara, J.Lopez, A.Kuznetsov, L.H.Philipson, and A.S.Chong, Recovery of islet cell function in streptozotocin induced diabetic mice, Diabetes, 55, 2006,3256-336

[36] Suharingsih, D.Winarni, S.A.Husen, Muzaki, T.A.Priyo, Uji penggunaan matras cursonic untuk menurunkan kadar gula darah penderita diabetes melitus tipe 2. Report of research, Universitas airlangga, 2009.

[37] E.K.Syamsul, A.E.Nugroho, and S.Pramono, The antidiabetic of combination metformin and purified extract of Andrographis panniculata (Burn.) in high fructose fat red rats, Majalah Obat Tradisional, 16(3), 2011, 124 - 131.

[38] A.Akbarzadeh, D.Norouzian,M.R.Mehrabi, S.H.Jamshidi, A.Farhangi, A.A.Verdi, S.M.A.Mofidian, and B.Lame Rad, Induction of diabetes by streptozotocin in rats, Indian Journal of Clinical Biochemistry, 22(2) , 2007,60-64.

[39] A.G. AlKushi, Biochemical and ultrastructure changes in the kidney of streptozotocin-induced diabetic rat, Pakistan Journal of Nutrition, 12(4), 2013, 313-321. 
[40] A.H. AlAssaf, Antihyperglycemic and antioxidant effect of ginger extract on streptozotocin-diabetic rats, Pakistan Journal of Nutrition, 11(12), 2012, 1107-1112.

[41] A.Vella, and R.A.Rizza, Metabolic disturbances in diabetes, in R.I.G. Holt, C. Cokram,A.Flyvbjerg,B.J.Goldstein, (eds), Textbook of diabetes, 4 (UK: A John Wiley \&Sons Ltd Publ., 2010)

[42] O.O.Erejuwa, S.A.Sulaiman, M.S.A. Wahab, K.N.S.Sirajudeen, M.D.Salzihan, S.Salleh, and M.D.Gurtu, Antioxidant protective effect of glibenclamide and metformin in combination with honey in pancreas of streptozotocin- induced diabetic rats, Int.J.Mol.Sci.,11, 2010, 2056-2066, doi:10.3390/ijms11052056.

[43] C. Kusano, and B. Ferrari, Total antioxidant capacity: a marker in biomedical and nutritional studies, Journal of Cell and Molecular Biology, 7(1), 2008,1-15.

[44] Judiono, Djokomoeljanto, and Hadisaputro, Biomolecular aspects of plain kefir antidiabetic potentials, International Journal of Food, Nutrition \& Public Health, 5(2), 2012, 7-23.

[45] R.Tsao, Chemistry and biochemistry of distary polyphenol, Nutrients, 2, 2012, 1231-1246.

[46] T.O.Alago, M.O.Edema, A.O.Atayese, and M.O.Bankole, Phytochemical and in vitro anti bacterial properties of Hibiscus sabdariffa Linn. (roselle) juice, J.Med.Plant Res., 8(6), 2014, 339-344.

[47] D.K.Sharma,C.Varshneya, B.S.More, and P.Bhardwaj, Effect of methanolic extract of _Carosea leaves o glycemic control antioxidant status in alloxan induced diabetes I rats, Pharmacologyonline, 3, 2011, 864-868. 